\title{
MEMPELAJARI KANDUNGAN GIZI TEPUNG AMPAS KELAPA DARI PENGOLAHAN VIRGIN COCONUT OIL (VCO) DAN MINYAK KOPRA PUTIH
}

\section{THE STUDY OF NUTRIENT CONTENT OF COCONUT GROUNDS FLOUR FROM THE PROCESSING OF VIRGIN COCONUT OIL (VCO) AND WHITE COPRA}

\author{
Hilda F. G. Kaseke \\ Balai Riset dan Standardisasi Industri Manado \\ Jalan Diponegoro No 21-23 \\ e-mail: kasekehilda@yahoo.co.id
}

\begin{abstract}
ABSTRAK
Penelitian kandungan gizi tepung ampas kelapa dari pengolahan Virgin Coconut Oil (VCO) dan minyak kopra putih sebagai sumber pangan fungsional telah dilakukan dengan menggunakan metode deskriptif eksperimental.Tujuan penelitian untuk melihat kandungan gizi kue dari tepung ampas kelapa dari VCO dan ampas kopra putih. Pengamatan dilakukan terhadap proksimat dari kue kelapa coek. Uji proksimat meliputi kadar protein, karbohidrat, kadar lemak, serat kasar, kadar abu, kadar air, vitamin $A, D, E$, serat pangan terlarut dan tidak terlarut. Hasil penelitian menunjukkan bahwa kandungan gizi yang terdapat pada ampas kelapa dari VCO yaitu kadar serat kasar 17,6\%, kadar lemak 42,7\%, kadar protein $6 \%$, karbohidrat $45 \%$, serat pangan terlarut $7,14 \%$, serat pangan tidak terlarut $43,8 \%$, vitamin $A<0,5$ $\mathrm{IU} / 100 \mathrm{~g}$, vitamin $\mathrm{D} 10,5 \mu \mathrm{g} / 100 \mathrm{~g}$ dan vitamin $\mathrm{E}<0,1 \mathrm{mg} / 100 \mathrm{~g}$. Kandungan gizi yang terdapat pada kue ampas kelapa dari kopra putih yaitu serat kasar 14,6\%, kadar lemak 35,3\%, kadar protein 9,0\%, kadar karbohidrat 49\%, serat pangan larut 4,91\%, serat pangan tidak larut 29,7\%, vitamin $A<0,5 \mathrm{IU} / 100 \mathrm{~g}$, vitamin D 4,93 $\mu \mathrm{g} / 100 \mathrm{~g}$, dan vitamin $\mathrm{E}<0,1 \mathrm{mg} / 100 \mathrm{~g}$. Perlakuan ampas VCO 75\% adalah perlakuan terbaik.Kandungan gizi tertinggi didapatkan pada perlakuan ampas VCO.
\end{abstract}

Kata kunci : ampas VCO, kopra putih, kelapa cook

\section{ABSTRACT}

The study of nutrient content of coconut grounds flour from the processing of Virgin Coconut Oil (VCO) and white copra oil food have been done by using descriptive experimental method. The objective of the study was to see the nutrient content of coconut dregs flour from VCO and white copra oil. Observations were made to proklamate analysis of the coconut cake. Proximate analysis includes protein, carbohydrate, fat content, coarse fiber, ash content, water content, vitamin $A, D$, E, soluble and nonsoluble fiber. Nutrient content found in coconut pulp from VCO is: $17.6 \%$ crude fiber content, $42.7 \%$ fat content, protein content $6 \%$, carbohydrate $45 \%$, soluble fiber $7.14 \%$, unsoluble food fiber $43.8 \%$, vitamin $A<0.5 \mathrm{lU} / 100 \mathrm{~g}$, vitamin $D \mathrm{10,5} \mu \mathrm{g} / 100 \mathrm{~g}$ and vitamin $E<0,1 \mathrm{mg} / 100 \mathrm{~g}$. The nutrient contents found in coconut pulp from white copra are crude fiber $14.6 \%$, fat content $35.3 \%$, protein content $9.0 \%$, carbohydrate $49 \%$, soluble fiber $4.91 \%$, insoluble food fiber $29,7 \%$, vitamin $A<0.5 \mathrm{IU} / 100 \mathrm{~g}$, vitamin $D$ $4.93 \mu \mathrm{g} / 100 \mathrm{~g}$, and vitamin $E<0.1 \mathrm{mg} / 100 \mathrm{~g}$. Coconut grounds from VCO and white copra still contains nutrients. The best treatment was found in 75\% VCO Absorbent Treatment. The highest nutrient content is found on the VCO dregs.

Keywords : coconut cookies, coconut gounds flour, white copra

\section{PENDAHULUAN}

Dari berbagai cara pembuatan minyak kelapa, selain menghasilkan minyak kelapa juga menghasilkan ampas kelapa yang terbuang percuma, di mana ampas tersebut masih mengandung bahan-bahan nutrisi. Banyak cara pembuatan minyak seperti minyak klentik, VCO, minyak fermentasi, minyak kopra putih, yang kesemuanya menghasilkan produk samping ampas kelapa. Ampas kelapa diduga masih banyak mengandung nutrisi seperti protein, lemak, karbohidrat. Namun keunggulan utama ampas kelapa adalah kandungan serat pangan yang tinggi. Saat ini 
kebutuhan makanan bergeser menjadi makanan fungsional dan jelas masih terus berkembang di samping fungsinya yang semakin bervariasi.

Pola makanan dan gaya hidup tidak sehat dewasa ini memicu timbulnya penyakit seperti obesitas, osteoporosis, diabetes, kanker, dan penyakit jantung sehingga tuntutan dan kebutuhan konsumen terhadap makanan telah berubah, di mana konsumen cenderung menginginkan makanan yang dapat memberikan manfaat bagi kesehatan. Dewasa ini, ada kecenderungan orang mengkonsumsi makanan tidak hanya semata mata mempertimbagkan nilai gizi dan rasanya, tetapi juga pengaruh makanan tersebut pada kesehatan tubuhnya. Makanan yang dikonsumsi harus diusahakan dapat menjaga kesehatan dan kebugaran, dan mencegah munculnya efek negatif bagi tubuh konsumen.

Kopra putih adalah nama lain dari kopra yang memiliki kualitas jumlah lebih baik dari kopra asap karena kopra putih memiliki beberapa kelebihan dibanding kopra asap. Kelebihan itu diantaranya kopra putih memiliki kadar air yang cukup rendah hingga 5-6\%, kopra putih relatif bebas dari serangan cendawan dan warnaya jauh lebih putih dan bersih. Kopra putih bebas dari aroma yang ditimbulkan dari proses pengasapan sehingga lebih higienis dibanding dengan kopra asap. Ampas kelapa yang diperoleh dari berbagai cara pengolahan kelapa sampai saat ini belum diketahui kandungan gizi yang lengkap dan kondisi ampas yang terbaik.

Pengolahan untuk mendapatkan minyak ada berbagai cara sehingga ampas yang dihasilkan pasti berbeda satu dengan yang lainnya. Oleh sebab itu perlu dilakukan penelitian untuk memperoleh kandungan gizi dari ampas yang didapat dan kadar proksimat. Dengan didapatkan data tersebut sangat bermanfaat sebagai dasar ampas kelapa sebagai sumber.

\section{Tujuan Penelitian}

Untuk melihat kandungan gizi dari kue tepung ampas kelapa dan kadar proksimat dari VCO dan ampas kopra putih sebagai sumber pangan fungsional.

\section{BAHAN DAN METODE}

\section{Bahan Dan Alat}

Bahan utama yang digunakan adalah tepung VCO dan tepung ampas kopra putih.Bahan pembantu lainnya adalah mentega, gula pasir, tepung terigu, esens vanili dan telur.

Alat-alat yang digunakan adalah oven, penggilig kelapa, mesin penghancur, alat pencacah, kompor, Loyang, gas dan saringan.

\section{Metode Penelitian}

Penelitian dilakukan dengan metode deskriptif eksperimental, dengan perlakuan sebagai berikut :

$\mathrm{A} 0=$ ampas kelapa VCO $100 \%$ : tepung terigu $0 \%$

$\mathrm{A} 1=$ ampas kelapa $\mathrm{VCO} 75 \%$ : tepung terigu $25 \%$

$\mathrm{A} 2=$ ampas kelapa VCO 50\% : tepung terigu $50 \%$

$\mathrm{A} 3=$ ampas kelapa VCO 25\% : tepung terigu $75 \%$

$\mathrm{B} 0=$ ampas kelapa kopra putih 100\% : tepung terigu $0 \%$

B1= ampas kelapa kopra putih 75\% : tepung terigu $25 \%$ 
B2= ampas kelapa kopra putih 50\% : tepung terigu $50 \%$

B3= ampas kelapa kopra putih 25\% : tepung terigu $75 \%$

\section{Prosedur Penelitian}

1. Pembuatan ampas VCO

Kelapa diparut, selanjutnya ditambahkan air kemudian dipisahkan antara ampas dan santan. Ampas yang dihasilkan dikeringkan dalam oven setelah ampas kering digiling menjadi tepung.

2. Pembuatan ampas kopra putih

Kelapa dikeluarkan sabut dan tempurungnya kemudian dagingnya dikeringkan dalam oven. Sesudah itu dipisahkan ampas dan minyaknya dengan cara diperas menggunakan mesin pemeras. Akhirnya ampas digiling menjadi tepung.

3. Pembuatan kelapa Coek

- Siapkan tepung yang dibutuhkan.

- Campur tepung ampas dengan terigu sesuai perlakuan.
- Mentega sebanyak 100 g dicampur dengan gula halus $90 \mathrm{~g}$, garam $4 \mathrm{~g}$, natrium bikarbonat $1 \mathrm{~g}$ dan susu bubuk $30 \mathrm{~g}$.

- Masukkan campuran tepung ke campuran lemak sampai homogen kemudian ditambahkan air $160 \mathrm{ml}$.

- Adonan siap dicetak kemudian dipanggang dalam oven sampai matang.

\section{Pengamatan}

Untuk melihat kandungan gizi dari kue ampas kelapa VCO dan kopra putih sebagai sumber pangan fungsional dilakukan analisa: Proksimate (serat kasar, protein, karbohidrat, abu dan kadar air, lemak), serat pangan terlarut dan tidak terlarut serta vitamin A D E.

\section{HASIL DAN PEMBAHASAN}

Hasil

Tabel 2. Komposisi analisis kue kelapa coek dari ampas vco dan kopra putih

\begin{tabular}{ccccccc}
\hline Perlakuan & $\begin{array}{c}\text { Serat Kasar } \\
(\%)\end{array}$ & $\begin{array}{c}\text { Kadar Air } \\
(\%)\end{array}$ & $\begin{array}{c}\text { Kadar } \\
\text { Lemak (\%) }\end{array}$ & $\begin{array}{c}\text { Kadar } \\
\text { Abu (\%) }\end{array}$ & $\begin{array}{c}\text { Kadar } \\
\text { Protein (\%) }\end{array}$ & $\begin{array}{c}\text { Karbohidrat } \\
(\%)\end{array}$ \\
\hline $\mathrm{A}_{0}$ & 17,6 & 4,6 & 42,7 & 1,2 & 6,0 & 45 \\
$\mathrm{~A}_{1}$ & 13,3 & 4,7 & 40,3 & 1,1 & 5,0 & 49 \\
$\mathrm{~A}_{2}$ & 13,0 & 4,6 & 37,4 & 1,1 & 4,0 & 53 \\
$\mathrm{~A}_{3}$ & 10,7 & 4,8 & 32,8 & 1,1 & 3,0 & 58 \\
$\mathrm{~B}_{0}$ & 14,6 & 4,6 & 35,3 & 2,1 & 9,0 & 49 \\
$\mathrm{~B}_{1}$ & 13,8 & 4,5 & 34,3 & 1,9 & 8,0 & 52 \\
$\mathrm{~B}_{2}$ & 13,4 & 4,6 & 33,5 & 1,5 & 6,0 & 55 \\
$\mathrm{~B}_{3}$ & 12,7 & 4,6 & 32,5 & 1,3 & 6,0 & 56 \\
$\mathrm{~A}$ & 33,19 & 6,73 & 40,49 & 1,89 & 5,43 & 47 \\
$\mathrm{~B}$ & 17,21 & 8,56 & 15,74 & 4,55 & 19,62 & 50 \\
\hline
\end{tabular}

Tabel 3.Kandungan serat pangan dan vitamin pada kue kelapa coek

\begin{tabular}{cccccc}
\hline Kode & $\begin{array}{c}\text { Serat } \\
\text { Pangan } \\
\text { Larut (\%) }\end{array}$ & $\begin{array}{c}\text { Serat Pangan } \\
\text { Tidak Larut (\%) }\end{array}$ & $\begin{array}{c}\text { Vit. A } \\
(\mathrm{IU} / \mathbf{1 0 0} \\
\mathbf{g})\end{array}$ & $\begin{array}{c}\text { Vit. D } \\
(\boldsymbol{\mu} \mathbf{g} / \mathbf{1 0 0} \mathbf{g})\end{array}$ & $\begin{array}{c}\text { Vit. E } \\
(\mathbf{m g} / \mathbf{1 0 0} \mathbf{~ g})\end{array}$ \\
\hline $\mathrm{A}$ & 7,14 & 43,8 & $<0,5$ & 10.5 & $<0,1$ \\
$\mathrm{~B}$ & 4,91 & 29,7 & $<0,5$ & 4,93 & $<0,1$ \\
$\mathrm{~A}_{1}$ & 1,37 & 7,51 & $-^{*}$ & $-^{*}$ & $-^{*}$ \\
$\mathrm{~A}_{2}$ & 0,75 & 3,04 & $-^{*}$ & $-^{*}$ & $-^{*}$ \\
$\mathrm{~B}_{1}$ & 1,20 & 7,50 & $-^{*}$ & $-^{*}$ & $-^{*}$ \\
$\mathrm{~B}_{2}$ & 1,10 & 1,11 & & &
\end{tabular}




\section{Pembahasan}

\section{Serat Kasar}

Serat kasar dari ampas VCO lebih tinggi dari ampas kopra putih yaitu 31,19\% dan $7,21 \%$. Dapat dilihat pada gambar 1.Setelah diproses menjadi kue kelapa cook, serat kasar dari kue yang dibuat menggunakan ampas VCO, berkisar 10,7$17,6 \%$ dan ampas kopra putih 12,7-14,6\%. Kue kelapa yang dibuat dari ampas VCO lebih tinggi kadar serat kasarnya dibanding dengan kue kelapa menggunakan ampas kopra putih. Hal ini ada kaitannya dengan bahan baku, dimana sejak awal bahan baku ampas dari VCO sudah lebih tinggi dari ampas kopra putih yaitu $31,19 \%$ dan 17,21\%. Putri (2010) mengungkapkan bahwa kadar serat dari ampas kelapa cukup tinggi yaitu $15,0685 \%$, makin banyak ampas yang ditambahkan dalam pembuatan kue maka makin tinggi serat kasar yang di dapatkan.

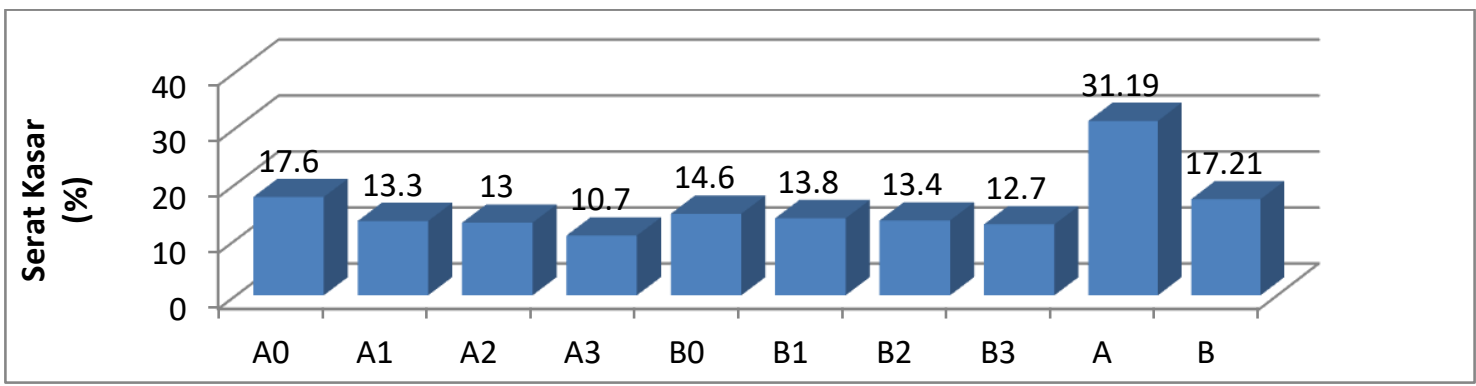

$A_{0}=$ ampas vco $100 \%, A_{1}=75 \%, A_{2}=50 \%, A_{3}=25 \%, B_{0}=$ ampas kopra putih $100 \%, B_{1}=75 \%, B_{2}=50 \%$, $B_{3}=25 \%, A=$ ampas VCO, $B=$ ampas kopra putih.

Gambar 1.Serat kasar dari kue ampas kue coek vco dan kopra putih

\section{Kadar Air}

Pada penelitian ini kadar air dari ampas VCO dan ampas kopra putih, yang dibuat kue berkisar 4,5-4,8\%. Kadar air dari ampas VCO 6,73\% dan ampas kopra putih $8,56 \%$ terlihat pada gambar 2. Meskipun bahan baku awal berbeda kadar airnya, tapi setelah dibuat kue kadar air sama kisarannya cukup rendah karena penggunaan suhu oven pembakaran yang sama sampai kering. Tepung ampas kelapa dengan kadar air rendah dapat disimpan lebih lama, sehingga dapat dijual atau dipergunakan sesuai kebutuhan, Putri (2010), menyatakan kadar air dari tepung ampas VCO berkisar 6,9969\%. Rendahnya kadar air disebabkan karena kue yang dipanggang dengan menggunakan oven sampai kering.

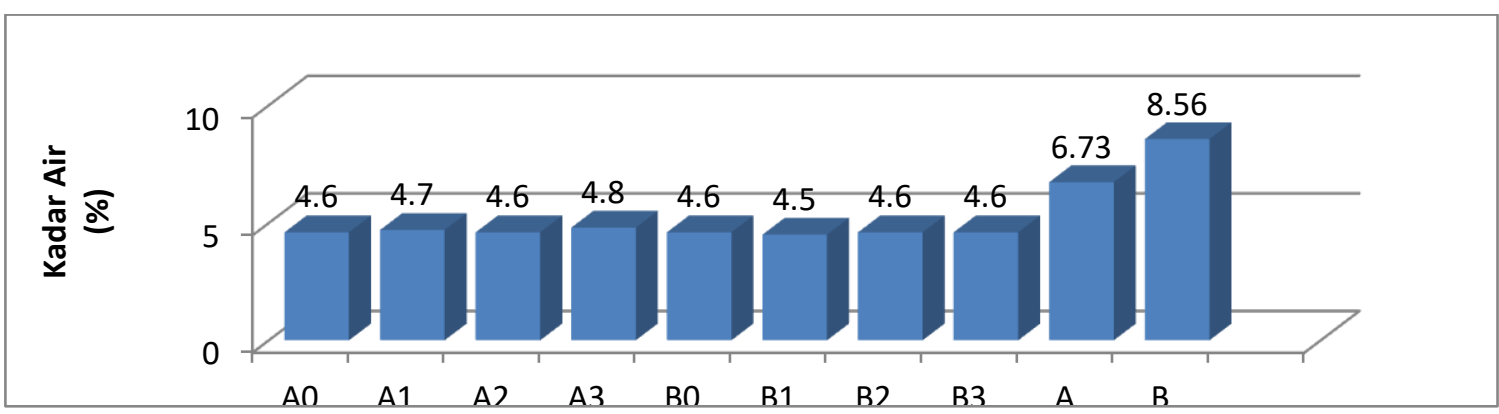

$A_{0}=$ ampas vco $100 \%, A_{1}=75 \%, A_{2}=50 \%, A_{3}=25 \%, B_{0}=$ ampas kopra putih $100 \%, B_{1}=75 \%, B_{2}=$ $50 \%, B_{3}=25 \%, A=$ ampas VCO, B = ampas kopra putih.

Gambar 2.Kadar Air Kue Kelapa dari Ampas VCO dan Kopra Putih. 


\section{Kadar Lemak}

Kadar lemak dari kue yang dihasilkan dari ampas VCO lebih tinggi dibanding dari ampas kopra putih yaitu (32,8-42,7\%) dan $(32,5-35,3 \%)$ demikian juga dengan kadar lemak sebelum dibuat produk kue, yaitu 40,49\% dan $15,74 \%$ untuk ampas dari VCO dan ampas kopra putih.

Hal ini disebabkan karena dalam pembuatan menjadi tepung, daging kelapa dari kopra putih dilakukan pengeluaran minyak dengan alat press, sedangkan yang dibuat dari VCO hanya menggunakan tenaga manusia.

Tepung dengan kadar lemak yang tinggi berpotensi sebagai sumber lemak nabati yang memiliki efek positif pada kesehatan, apalagi jika diketahui jenis asam lemak yang ada dalam tepung ampas kelapa. Kadar lemak dari kue yang dibuat dari ampas kopra putih lebih tinggi dibanding kadar lemak bahan baku karena dalam pembuatan kue ditambahkan mentega menyebabkan kadar lemaknya meningkat.

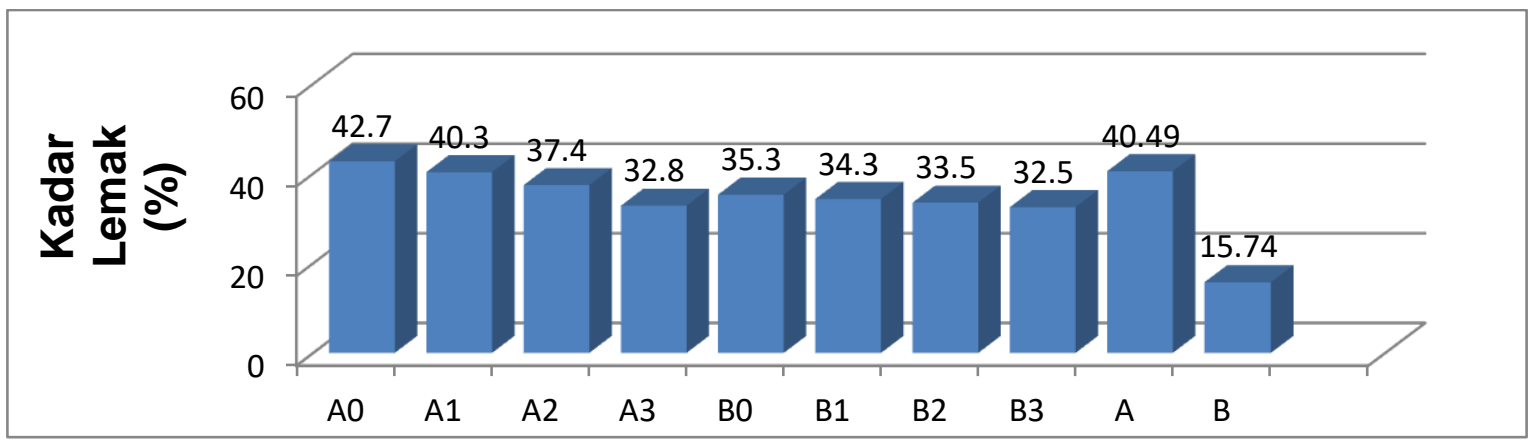

$A_{0}=$ ampas vco $100 \%, A_{1}=75 \%, A_{2}=50 \%, A_{3}=25 \%, B_{0}=$ ampas kopra putih $100 \%, B_{1}=75 \%, B_{2}=50 \%$, $B_{3}=25 \%, A=$ ampas VCO, $B=$ ampas kopra putih.

Gambar 3. Kadar lemak kue kelapa dari ampas vco dan kopra putih

\section{Kadar Abu}

Kadar abu dari kue yang dibuat dari ampas VCO berkisar 1,1-1,2\%, dan dari ampas kopra putih 1,3-2,1\%. Kadar abu dari ampas kopra putih $4,55 \%$ dan dari VCO $1,89 \%$ (dapat dilihat pada gambar 4 ).
Kadar abu kue yang dibuat dari ampas VCO berkisar 1,2-1,1\% dan dari ampas kopra putih 1,09-2,1\%. Diduga karena bahan baku ampas sudah jauh berbeda yaitu $8,9 \%$ dari VCO dan $4,55 \%$ dari ampas kopra putih.

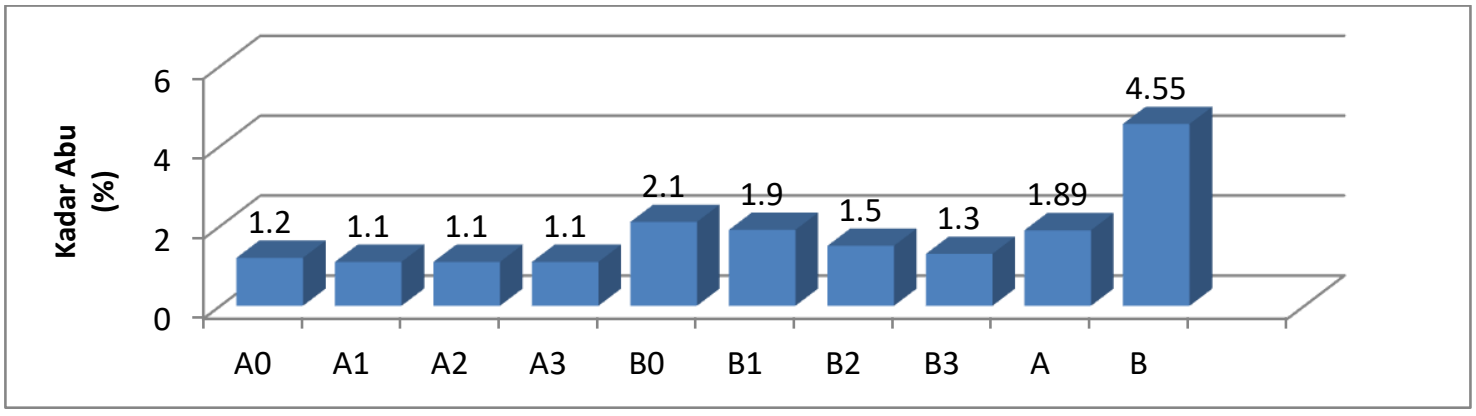

$A_{0}=$ ampas vco $100 \%, A_{1}=75 \%, A_{2}=50 \%, A_{3}=25 \%, B_{0}=$ ampas kopra putih $100 \%, B_{1}=75 \%, B_{2}=50 \%$, $B_{3}=25 \%, A=$ ampas VCO, $B=$ ampas kopra putih.

Gambar 4.Kadar Abu Kue Kelapa dari Ampas VCO dan Kopra Putih. 


\section{Kadar Protein}

Dari Gambar 5 dan tabel 2 terlihat bahwa kadar protein dari kue yang dibuat dari ampas VCO berkisar pada 3-6\%, dan kue dari ampas kopra putih berkisar 6,0-9,0\%. Tepung ampas kelapa dapat dijadikan sumber protein karena kandungan proteinnya cukup tinggi $8,43 \%$ untuk ampas dari VCO dan $9,62 \%$ dari ampas kopra putih.
Protein dari ampas kopra putih lebih tinggi dari VCO, di duga pada saat pemerasan VCO menggunakan air sehingga banyak protein yang terikut pada santan, sedangkan dalam proses pemerasan ampas kopra putih tidak menggunakan air hanya menggunakan tekanan dan kadar air dari kopra putih juga sudah cukup rendah sehingga tidak terikut dalam proses pemerasan.

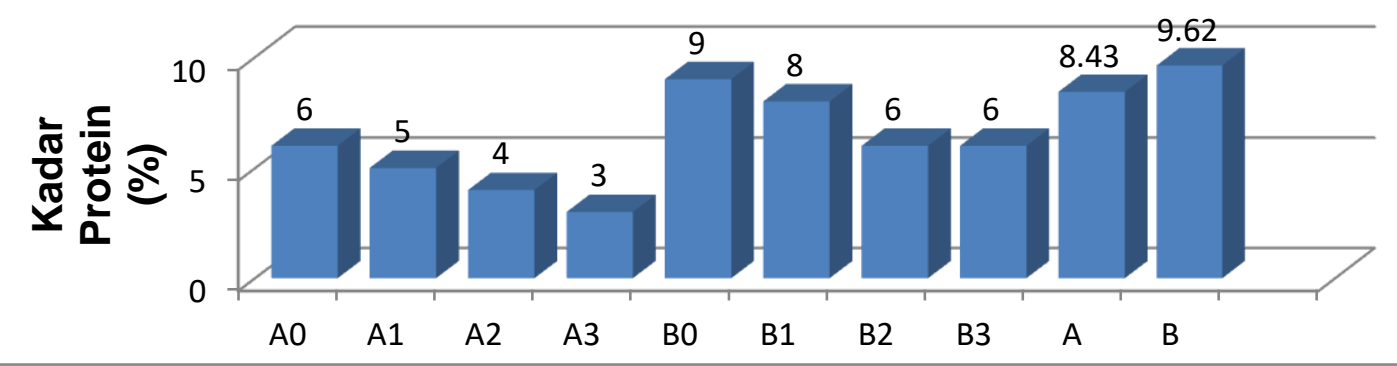

$A_{0}=$ ampas vco $100 \%, A_{1}=75 \%, A_{2}=50 \%, A_{3}=25 \%, B_{0}=$ ampas kopra putih $100 \%, B_{1}=75 \%, B_{2}=50 \%$, $B_{3}=25 \%, A=$ ampas VCO, $B=$ ampas kopra putih.

Gambar 5. Kadar protein kue kelapa dari ampas vco dan kopra putih

\section{Kadar Karbohidrat}

Karbohidrat dari ampas kelapa yang dibuat dari VCO 47\% dan dari ampas kopra putih 40\% (dapat dilihat pada Tabel 2 dan Gambar 6). Karbohidrat dari kue kelapa cook yang berasal dari VCO berkisar 45$48 \%$ dan dari ampas kopra putih berkisar
49-56\%, yang berarti bahwa cukup tinggi karbohidrat yang terkandung dari ampas vCO dan kopra putih, yang mengindikasikan kandungan gizi cukup tinggi dapat digunakan sebagai sumber karbohidrat.

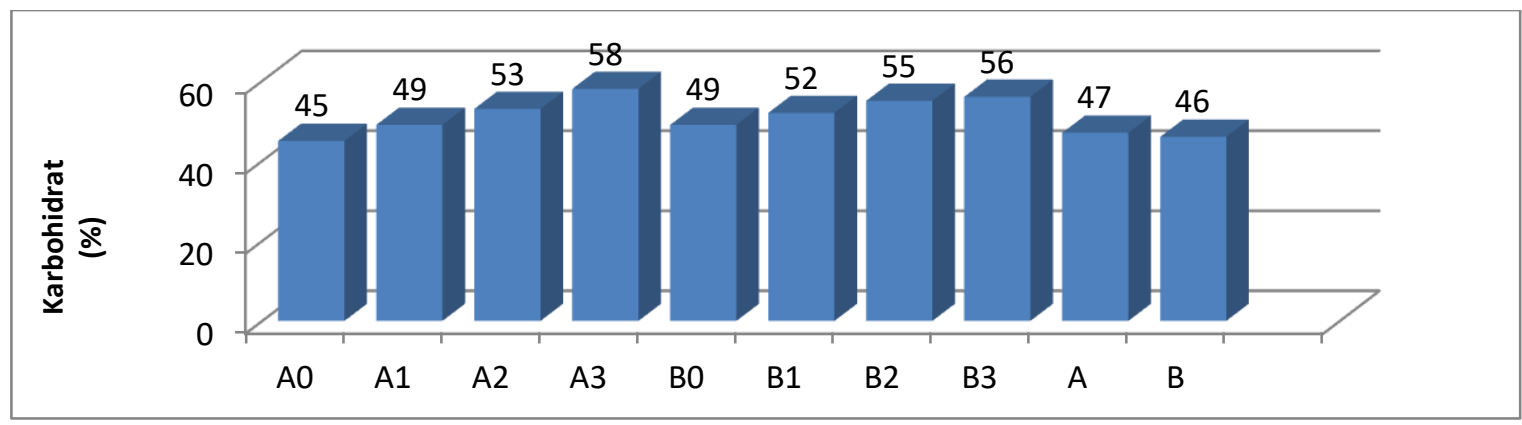

$A_{0}=$ ampas vco $100 \%, A_{1}=75 \%, A_{2}=50 \%, A_{3}=25 \%, B_{0}=$ ampas kopra putih $100 \%, B_{1}=75 \%, B_{2}=50 \%$, $B_{3}=25 \%, A=$ ampas VCO, $B=$ ampas kopra putih.

Gambar 6. Kadar Karbohidrat Kue Kelapa dari Ampas VCO dan Kopra Putih. 


\section{Serat Pangan Terlarut}

Serat pangan larut dari ampas VCO lebih tinggi dari ampas kopra putih yaitu $7,14 \%$ dan 4,91\%, tapi kedua-duanya cukup rendah serat pangan terlarut. Hal ini berdampak pada kue kelapa Cook yang dibuat yaitu $0,75-1,37 \%$ dari kue yang dibuat dari ampas VCO dan 1,10-1,20\% dari kue yang dibuat dari ampas kopra putih.

\section{Serat Pangan Tidak Larut}

Serat pangan tidak larut dari ampas VCO lebih tinggi dari ampas kopra putih yaitu 43,8\% dan 29,7\%, tapi keduanya cukup tinggi. Karena kandungan serat pangan tidak larut cukup tinggi oleh karena itu tepung ampas kelapa baik dari VCO dan ampas kopra putih dapat dijadikan jenis tepung ampas kelapa sebagai sumber serat pangan.

Raghavendran et.al, (2004). dalam Putri (2010) menyatakan serat pangan $63,04 \%$ terdiri dari serat larut $4,33 \%$ dan serat tidak larut $58,71 \%$ ditemukan cukup pada ampas kelapa, komposisi ini cukup tinggi dengan serat pangan dari sumber lain yang terdapat secara komersial dan serat pangan sebagai komponen fungsional pangan sehingga memberi efek positif pada kesehatan jantung. Hal ini sama halnya dengan kue yang dibuat dari ke dua ampas tersebut di mana kue yang dibuat dari ampas VCO lebih tinggi serat pangan tidak larut dibanding kue dari ampas VCO dan kopra putih yaitu 3,04-7,51\% dan 1,17,40\% (Tabel 3).

\section{Vitamin A, Vitamin D dan E.}

Vitamin $\mathrm{A}<0,5 \mathrm{iu} / \mathrm{l00} \mathrm{g}$ dan vitamin $\mathrm{E}$ $<0,1 \mathrm{mg} / 100 \mathrm{~g}$ sama untuk kedua bahan baku, baik ampas dari VCO dan kopra putih. Tetapi vitamin D ampas VCO 10 $\mathrm{mg} / 100 \mathrm{~g}$ lebih tinggi dari ampas kopra putih yaitu $4,93 \mu \mathrm{g} / 100 \mathrm{~g}$.

\section{KESIMPULAN}

Kandungan gizi yang terdapat pada ampas kelapa dari VCO yaitu kadar serat kasar 17,6\%, kadar lemak $42,7 \%$, kadar protein $6 \%$, karbohidrat $45 \%$, serat pangan terlarut $7,14 \%$, serat pangan tidak terlarut $43,8 \%$, vitamin $A<0,5 \mathrm{IU} / 100 \mathrm{~g}$, vitamin $D$ $10,5 \mu / 100 \mathrm{~g}$ dan vitamin $\mathrm{E}<0,1$ $\mathrm{mg} / 100$ g. Kandungan gizi yang terdapat pada ampas kelapa dari kopra putih yaitu serat kasar 14,6\%, kadar lemak 35,3\%, kadar protein 9,0\%, kadar karbohidrat 49\%, serat pangan larut $4,91 \%$, serat pangan tidak larut $29,7 \%$, vit. $\mathrm{A}<0,5 \mathrm{IU} / 100 \mathrm{~g}$, vit. D 4,93 IU/100 g dan vit. $\mathrm{E}<0,1$ $\mathrm{mg} / 100 \mathrm{~g}$.

- Ampas kelapa dari VCO dan kopra putih dapat dijadikan sebagai sumber pangan fungsional karena masih mengandung gizi.

- Perlakuan ampas VCO $75 \%$ yang terbaik.

- Kandungan gizi tertinggi didapatkan pada ampas VCO.

\section{DAFTAR PUSTAKA}

1. https://id.wikipedia.org/wiki/Seratpangan ,diakses 18 Maret 2016.

2. https://id.wikipedia.org/wiki/Pangan fun gsional, diakses 18 Maret $201 \overline{6}$. 
3. Astawan, M 2003, 'Pangan fungsional untuk kesehatan yang optimal', Kompas Sabtu, vol. 23.

4. Astawan, M \& W. Tutik, 2004, 'Sehat Bersama Aneka Serat Pangan Alami', Tiga Serangkai, Solo.

5. Cordova, F 2015, 'eksperimen Pembuatan Pangsit Goreng Dengan Penambahan Ikan Teri NasiDan Wortel', Universitas Negeri Semarang.

6. Indrasari, SD \& M.O. Adnyana, 2007, 'Preferensi konsumen terhadap beras merah sebagai sumber pangan fungsional', Buletin Iptek Tanaman Pangan, vol. 2, no. 2.

7. Miskiyah, IM \& W. Haliza, 2006, 'Pemanfaatan ampas kelapa limbah pengolahan minyak kelapa murni menjadi pakan', in Presiding Seminar Nasional Tekhnologi Peternakan dan Verteriner.

8. Muchtadi, D 2001, 'Sayuran sebagai sumber serat pangan untuk mencegah timbulnya penyakit degeneratif.Jurnal Teknologi dan Industri Pangan, vol. 12, no. 1.

9. Putri, MF 2010, 'Kandungan Gizi Dan Sifat Fisik Tepung Ampas Kelapa Sebagai Bahan Pangan Sumber Serat', Teknobuga, vol. 2, no. 1.

10.Santoso, IA 2011, 'Serat pangan (dietary fiber) dan manfaatnya bagi kesehatan', Magistra, vol.23, no. 75, p. 35.

11.Widyaningsih, T 2006, 'Pangan Fungsional: Makanan Untuk Kesehatan', Universitas Brawijaya. Malang.

12.Wijaya, C 2002, 'Pangan fungsional dan kontribusinya bagi kesehatan', in Makalah ini disampaikan pada Seminar Online Kharisma ke-2, Dengan Terna: Menjadi Ratu Dapur Profesional: Mengawal kesehatan keluargamelalui pemilihan dan pengolahan panganyang tepat. 